\title{
Growth of Geographic Atrophy in the Comparison of Age-related Macular Degeneration Treatments Trials (CATT)
}

\author{
Juan E Grunwald ${ }^{1}$, Maxwell Pistilli ${ }^{1}$, Gui-shuang Ying ${ }^{1}$, Maureen G Maguire ${ }^{1}$, Ebenezer \\ Daniel ${ }^{1}$, Daniel F Martin ${ }^{2}$, and for the CATT Research Group \\ ${ }^{1}$ Department of Ophthalmology, Perelman School of Medicine, University of Pennsylvania, \\ Philadelphia, Pennsylvania \\ ${ }^{2}$ Cole Eye Institute, Cleveland Clinic, Cleveland, Ohio
}

\section{Abstract}

Purpose-To evaluate the growth of geographic atrophy (GA) during anti-VEGF therapy.

Design-Cohort within clinical trial.

Participants-Patients included in the Comparison of Age-related Macular Degeneration (AMD) Treatments Trials (CATT)

\begin{abstract}
Methods-Participants were randomly assigned to injections of ranibizumab or bevacizumab and to a 2-year dosing regimen of monthly or pro re nata (PRN), or to monthly for 1 year and PRN the following year. Digital color photographs and fluorescein angiograms at baseline, 1 and 2 years were evaluated for GA and the total area of GA was measured by two graders masked to treatment; differences were adjudicated. Multivariate linear mixed models of the annual change in the square root of the area included baseline demographic, treatment, and ocular characteristics on imaging as candidate risk factors.
\end{abstract}

Main outcome measures-GA growth rate.

Results-Among 1185 participants, 86 (7.3\%) had GA at baseline, 120 (10.1\%) developed GA during year 1 and $36(3.0 \%)$ during year 2. Among 194 eyes evaluable for growth, the rate was 0.43 (standard error [SE]: \pm 0.03 ) mm/year. In multivariate analysis, the growth rate was $0.37 \mathrm{~mm} /$ year in eyes receiving bevacizumab and $0.49 \mathrm{~mm} /$ year in eyes receiving ranibizumab (difference $0.11,95 \%$ Confidence Interval [CI]: $(0.01,0.22) ; \mathrm{p}=0.03)$. Growth rate did not differ between eyes treated monthly and PRN ( $\mathrm{p}=0.85)$. Eyes with subfoveal CNV lesions had a lower growth rate than eyes with non-subfoveal CNV lesions (difference 0.12, CI: 0.01, 0.22; $\mathrm{p}=0.03$ ). Eyes with

(C) 2014 by the American Academy of Ophthalmology. All rights reserved.

Corresponding Author: Juan E. Grunwald MD; Address: Department of Ophthalmology; University of Pennsylvania; 51 North $39^{\text {th }}$ Street; Philadelphia, PA 19104; juangrun@mail.med.upenn.edu Phone: 215-6628039, Fax: 215-6628025.

Publisher's Disclaimer: This is a PDF file of an unedited manuscript that has been accepted for publication. As a service to our customers we are providing this early version of the manuscript. The manuscript will undergo copyediting, typesetting, and review of the resulting proof before it is published in its final citable form. Please note that during the production process errors may be discovered which could affect the content, and all legal disclaimers that apply to the journal pertain.

Conflict of Interest: None

Financial Disclosure(s):

The author(s) have no proprietary or commercial interest in any of the materials discussed in this article. 
GA farther from the fovea had higher growth rates by 0.14 (CI: $0.01,27) \mathrm{mm} / \mathrm{year}$ for every $\mathrm{mm}$ farther from the fovea. The growth rate was $0.58 \mathrm{~mm} /$ year for eyes with predominantly classic lesions, $0.41 \mathrm{~mm} / \mathrm{year}$ for eyes with minimally classic lesions, and $0.30 \mathrm{~mm} / \mathrm{year}$ for eyes with occult only lesions $(\mathrm{p}<0.01)$. The growth rate in eyes having a fellow eye with GA was higher by 0.13 (CI: $0.01,0.24 ; \mathrm{p}=0.03$ ) $\mathrm{mm} / \mathrm{year}$ than in eyes without GA in the fellow eye. Eyes with epiretinal membrane had a higher growth rate than eyes without epiretinal membrane (difference 0.16 , CI: $(0.03,0.30 ; \mathrm{p}=0.02)$.

Conclusion-GA growth depends on several ocular factors. Ranibizumab may accelerate GA growth.

\section{Introduction}

Age-related macular degeneration (AMD) is a leading cause of vision loss in elderly people in the United States. ${ }^{1}$ Loss of vision from this disease is mostly due to the development of neovascular AMD and/or geographic atrophy (GA).

Intravitreal injections of anti-vascular endothelial growth factor (VEGF) agents are currently used for the treatment of neovascular AMD with excellent visual acuity response ${ }^{2-6}$. One of the findings observed during therapy is the development of atrophy of retinal pigment epithelium and choriocapillaries that resembles the appearance of de novo $\mathrm{GA}^{7}$. Results from the Comparison of Age-related Macular Degeneration Treatments Trials (CATT) in which patients were treated for 2 years with the anti-VEGF agents ranibizumab or bevacizumab showed that the 2-year incidence of GA was approximately $18 \%{ }^{8}$. When GA was present at the fovea the visual acuity was markedly decreased. ${ }^{9}, 10$ Eyes treated with ranibizumab had a higher risk than eyes treated with bevacizumab, and eyes treated monthly had a higher risk than eyes treated pro re nata (PRN). ${ }^{11}$

There are no long-term follow-up studies of these atrophic lesions, and it is not known whether their histology, growth patterns, and functional effects are similar to those of de novo GA lesions that develop in areas where no neovascularization was present previously. Because atrophic lesions associated with treated neovascularization are clinically indistinguishable from de novo GA, they will be referred to as GA throughout this paper.

The purpose of this study was to evaluate GA growth during anti-VEGF therapy. We also assessed the association between GA growth and characteristics of the affected patients and eyes, including drug and dosing regimen. Finally, we investigated whether the growth of GA associated with the neovascular lesion is different from that of GA developing away from the neovascular lesion.

\section{Methods}

The CATT cohort and methods have been previously described ${ }^{8-11}$. The CATT cohort consisted of 1185 patients with AMD and untreated choroidal/retinal neovascularization (CNV) with either the CNV or its sequalae, such as intra-retinal fluid, subretinal fluid, serous pigment epithelial detachment, hemorrhage blocked fluorescence, involving the foveal center. Patients were enrolled in 43 clinical centers in the United States between 
February 2008 and December 2009. Inclusion criteria included age $\geq 50$ years and active untreated CNV secondary to AMD and visual acuity between 20/25 and 20/320 in the study eye. According to the CATT study protocol patients with foveal center GA were not eligible ${ }^{6}$. The study was approved by an institutional review board associated with each center, and was compliant with the Health Insurance Portability and Accountability Act regulations. All patients provided written informed consent. The CATT study was registered with ClinicalTrials.gov (NCT00593450). At enrollment, patients were randomly assigned to one of four treatment groups defined by drug (ranibizumab or bevacizumab) and by dosing regimen (monthly or PRN). At 1 year, patients initially assigned to monthly treatment retained their drug assignment but were re-assigned randomly, with equal probability, to either monthly or PRN treatment. Patients initially assigned to PRN treatment had no change in assignment and retained both their drug assignment and PRN dosing regimen for the second year.

At enrollment, patients provided a medical history and had bilateral color fundus photography (CP), fluorescein angiography (FA) and time domain optical coherence tomography (OCT). Follow-up examinations were scheduled every 28 days for two years. $\mathrm{CP}$ and FA were performed again at 52 weeks and 104 weeks.

Morphologic features of the study eyes at baseline were evaluated. ${ }^{8,9}$ Two trained and certified graders at the CATT Fundus Photograph Reading Center reviewed baseline and follow-up images for the signs of GA in the study eye, as well as, the fellow eye. Discrepancies between the two graders were adjudicated.

Both CP and FA were used in assessing and characterizing GA. The diagnosis of GA required the presence within the macular vascular arcades of one or more patches $\geq 250 \mu$ in the longest linear dimension of partial or complete depigmentation in the CP that had one or more of these additional characteristics: sharply demarcated borders seen in CP and/or FA, visibility of underlying choroidal vessels, excavated or punched out appearance on stereoscopy of CP or FA, uniform hyper-fluorescence bounded by sharp borders on late phase angiography. OCT scans were not used for the determination of the presence of GA.

GA detected on CP and/or FA at baseline was considered as prevalent GA. GA that was not detected at baseline but was present at year 1, 2 or both was considered as incident GA. We excluded from the study all participants with un-gradable photographs at baseline and those in which all follow up photographs were un-gradable or missing.

Image $\mathbf{J}$ software ${ }^{12}$ was used to measure the area of each individual GA lesion on a selected FA image. The drawing of GA was done manually on the same image by two independent graders. A scaling factor for this image was determined from the distance between the center of the fovea and the center of the disc. This distance was considered to be $4.5 \mathrm{~mm}$. When discrepancies between graders in the GA area were beyond $50 \%$ or $2 \mathrm{~mm}^{2}$, an open adjudication between the two graders was performed, a new single drawing was agreed upon and a new measurement was performed. Otherwise, the average of the areas determined by the two graders was used as the area measurement. The distance from the foveal center to the nearest edge of GA was also determined. Finally, for each individual GA lesion, we 
determined whether the location was clearly outside the area of the total CNV lesion apparent at any previous visit or the current visit. Total CNV lesion included CNV, contiguous hemorrhage, serous pigment epithelium detachment, scar, blocked fluorescence, non-geographic atrophy and GA.

For this project we re-graded photographs from CATT study eyes that had GA at one or more study visits. For each of these eyes, all study visit photographs were simultaneously examined for the presence of GA. Whenever GA was detected at the year-1 or 2 visits, the previous visits were carefully analyzed for the presence of GA. The methodology of this study, which emphasized the quantitative and qualitative assessment of GA, in which all visits of a participant were assessed at the same time, yielded some what different results from those shown in our previous papers. ${ }^{8,11}$ There were 14 eyes that had GA in the original grading but were reassessed as not having GA at baseline, year-1 or 2 visits in the new grading performed for the current study.

At the CATT OCT Reading Center, two certified readers independently analyzed all baseline scans for morphological characteristics. ${ }^{13}$ Readers evaluated the presence of intraretinal fluid (IRF), subretinal fluid (SRF), and fluid below the retinal pigment epithelium (sub-RPE). When fluid was present, readers noted the location of fluid relative to the foveal center. They also identified the presence of subretinal hyper reflective material (SHRM), epi-retinal membrane and vitreo-macular attachment. Readers measured the thickness at the foveal center of the: a) retina, b) sub-retinal fluid, and c) sub-retinal tissue complex (defined as the distance from the outer photoreceptor border of the retina to Bruch's membrane, excluding sub-retinal fluid). A Senior Reader reconciled any grading disagreements between the reader pair.

Four single nucleotide polymorphisms (SNPs) previously associated with the risk of developing AMD were evaluated for association with growth of GA: (1) complement factor $\mathrm{H}(\mathrm{CFH}) \mathrm{Y} 402 \mathrm{H}$ (rs1061170), (2) age-related maculopathy susceptibility 2 (ARMS2, also called LOC387715) A69S (rs10490924), (3) high temperature requirement factor A1 (HTRA1) (rs11200638) and (4) complement component 3 (C3) R80G (rs2230199) ${ }^{14,15}$. One SNP previously associated with protection against GA, toll-like receptor 3 (TLR3) (rs3775291) was also evaluated ${ }^{16}$.

\section{Statistical Methods}

A number of risk factors for GA growth were assessed. These included: a) demographic factors: age, sex, smoking, hypertension, dietary supplements; b) GA characteristics: area, number, location, distance from the fovea, presence of GA in the fellow eye; c) study eye characteristics: visual acuity, total choroidal neovascularization (CNV) lesion size, $\mathrm{CNV}$ type and location, retinal angiomatous proliferans (RAP) lesion, hemorrhage; d) OCT characteristics: intraretinal fluid, subretinal fluid, sub-RPE fluid, subretinal hyper-reflective material, epiretinal membrane. And e) treatment characteristics: drug (ranibizumab and bevacizumab), regimen (monthly and PRN).

Linear mixed-effects models were used to estimate GA growth. In these mixed-effects models, the GA area was modeled as a function of time (relative to its first observed GA), 
candidate risk factor(s), and interaction term(s) of risk factor(s) with time. Slopes and intercepts were modeled as random effects within subjects. We explored three approaches for modeling GA growth: (1) total GA area without transformation; (2) square root transformation ${ }^{17}$; (3) $\log$ transformation. We found that use of the square root transformation decreased the dependency of GA growth on baseline GA size when compared to the total GA area; log transformation did not decrease the dependence further. Therefore, the square root transformation was used for all subsequent analyses. Similar analyses were performed for modeling the growth rate of individual GA lesions, except that additional random slopes and intercepts were nested within subjects.

Each risk factor was first evaluated by univariate analysis (without adjustment for other covariates), using mixed effect models for GA growth. Dosing regimen (monthly or PRN) was represented as a time-dependent covariate to accommodate the second randomization at 52 weeks for patients initially assigned monthly treatment. The risk factors with a $P$ value less than 0.20 in the univariate analysis were included in a multivariate analysis so that the independent effect of each predictor could be assessed. The final multivariate model was created by applying a backward selection procedure that retained only those predictors with a $P$ value less than 0.05 , with the exception of drug and dosing regimen, which were included in all multivariate models. Adjusted mean growth rate and $95 \%$ confidence intervals $(95 \% \mathrm{CI})$ for the difference in mean growth rate between groups were calculated from the final multivariate linear models.

\section{RESULTS}

Among 1185 participants, 86 (7.3\%) had GA at baseline, 120 (10.1\%) developed GA during year 1 and 36 (3.0\%) during year 2 (Figure 1). Among the participants with GA, growth of GA could be determined from two or more visits in 81 prevalent cases and in 113 cases in which GA was detected in year 1. Among these patients, $151(\%)$ had blood drawn for genetic analysis.

Characteristics of prevalent and incident GA were generally similar, as shown in Table 1. Mean number of GA lesions was 2.06 (SD 1.67) for prevalent cases and 1.53 (1.05) for incident cases. Distance to the fovea was $0.71(0.44) \mathrm{mm}$ for prevalent cases and $0.48(0.41)$ $\mathrm{mm}$ for incident cases, including $5(6 \%)$ prevalent and 25 (16\%) incident cases of subfoveal GA (12\% of all cases). Because subfoveal GA at baseline was an exclusion criteria in CATT, this value is artificially low. Mean of total area of GA was $2.58(5.96) \mathrm{mm}^{2}$ for prevalent cases and $2.39(3.27) \mathrm{mm}^{2}$ for incident cases at the time of first GA detection.

Using the model for square root transformed total GA area, GA growth rate was 0.45 (SE $0.04) \mathrm{mm} /$ year for prevalent cases and $0.41(0.04) \mathrm{mm} / \mathrm{year}$ for incident cases with an overall growth of $0.43(0.03) \mathrm{mm} / \mathrm{year}$ (Table 2). Risk factors for faster GA growth were assessed by univariate analysis of data from combined prevalent cases and incident cases, the results were summarized in Table 2.

When prevalent and incident GA cases were considered together, ranibizumab treatment $(p=0.02)$, GA in the fellow eye $(p=0.02)$, area of GA when first observed $(p<0.01)$, not 
subfoveal location of $\mathrm{CNV}$, classic CNV lesion type ( $\mathrm{p}<0.001$ ), and presence of epiretinal membrane $(\mathrm{p}=0.04)$ were significantly associated with faster growth. No significant associations were observed between genotype and GA growth rate (Table 3, available at www.aaojournal.org).

Table 4 summarizes the results of the multivariate analysis. When all prevalent and incident cases were analyzed together, mean growth was $0.37(0.06) \mathrm{mm} / \mathrm{year}$ in eyes receiving bevacizumab and $0.49(0.06) \mathrm{mm} /$ year in eyes receiving ranibizumab, and this difference of $0.11 \mathrm{~mm} /$ year $(95 \%$ CI: $0.01,0.22)$ was statistically significant $(\mathrm{p}=0.03)$. Because the area of GA was marginally larger in eyes treated with renibizumab (Table 1) and concerns about the dependence of growth rate on initial area, we included the initial area in the model and we found that the initial area was not associated with the growth rate $(\mathrm{p}=0.56)$, and the estimated difference in growth rates remained $0.11 \mathrm{~mm} /$ year

No significant difference in mean growth rate was detected between eyes treated monthly and those treated on a PRN regimen. Subfoveal location of CNV lesion was associated with slower growth of GA $(0.37(0.06) \mathrm{mm} / \mathrm{year}$ than that of eyes where the CNV was not located in the sub-foveal area $(0.49(0.06) \mathrm{mm} / \mathrm{year} ; \mathrm{p}=0.03)$.

CNV lesion type was significantly associated with mean growth rate (Table 4, $\mathrm{p}<0.01$ ). Mean growth rates for all cases together were $0.58(0.08) \mathrm{mm} /$ year for predominantly classic CNV lesions, $0.41(0.08) \mathrm{mm} / \mathrm{year}$ for minimally classic lesions, and $0.30(0.05) \mathrm{mm} / \mathrm{year}$ for occult only lesions.

Participants with GA in the fellow eye showed significantly higher mean growth rate, 0.49 (0.06) $\mathrm{mm} /$ year, than participants that did not have GA in the fellow eye, $0.37(0.06) \mathrm{mm} /$ year $(\mathrm{p}=0.03)$. Finally, eyes with epi-retinal membrane had a higher mean growth rate, 0.51 $(0.07) \mathrm{mm} / \mathrm{year}$, than eyes without epi-retinal membrane, $0.35(0.06) \mathrm{mm} / \mathrm{year}(\mathrm{p}=0.02)$.

We observed no significant association between the number of injections given and the GA growth rate. Larger distance from the GA lesion to the fovea was associated with a significantly higher GA growth rate $(\mathrm{p}=0.03$, Table 4$)$.

Figure 2 shows a study eye in which GA lesions developed both in the area of the total CNV lesion and outside of the total CNV lesion.. There were 40 (47\%) cases of prevalent GA and $15(10 \%)$ cases among incident GA in which at least one individual GA lesion was outside of the total CNV lesion. Furthermore, 26 (65\%) of the 40 prevalent cases and only 2 (13\%) of the 15 incident cases did not have GA contiguous with the total CNV lesion.

Individual GA lesions first observed outside the total CNV lesion were smaller ( $\mathrm{n}=94$ lesions, mean $\left.0.70 \mathrm{~mm}^{2}\right)$ than those associated with the total CNV lesion $(\mathrm{n}=214$ lesions, $\left.1.07 \mathrm{~mm}^{2}, \mathrm{p}<0.001\right)$. The growth rate of individual GA lesions outside of the total CNV lesion was $0.20(0.05) \mathrm{mm} / \mathrm{year}$, whereas growth of the 214 lesions associated with the total CNV lesion was $0.29(0.04) \mathrm{mm} / \mathrm{year}$. The difference between these two types of GA was of borderline statistical significance $(\mathrm{p}=0.06)$. 


\section{DISCUSSION}

The overall GA growth rate in CATT, expressed as a square root transformation, was 0.43 $(0.03) \mathrm{mm} / \mathrm{year}$. This was similar to the square root transformed rate in two recent studies of dry AMD. Domalpally et $\mathrm{al}^{18}$ reported a growth rate of $0.4 \mathrm{~mm} / \mathrm{year}$ in 593 AREDS study eyes with GA (mean baseline area of 3.17 (SE: 0.19) $\mathrm{mm}^{2}$ ), and Yehoshua et al ${ }^{19}$ reported a growth rate of $0.37 \mathrm{~mm} /$ year in a small clinical trial of 30 AMD patients (mean baseline area of 4.4 (SE: 0.81) $\mathrm{mm}^{2}$ ). Previous methods of calculating GA growth rates, expressed in $\mathrm{mm}^{2}$, reported rates ranging from 1.28 to $2.6 \mathrm{~mm}^{2} /$ year. ${ }^{20-26}$ If we model the GA growth in CATT in $\mathrm{mm}^{2}$, the mean GA growth rate in our study is $1.65 \mathrm{~mm}^{2} /$ year (SE $0.15,95 \%$ CI: 1.36 to 1.94$)$, similar to previous reports.

It is of considerable interest that these growth rates, no matter how calculated, are similar to previous studies. All of these studies included patients with non-neovascular (dry) AMD, whereas, in CATT the GA was in neovascular AMD, and in most cases in the bed of previous choroidal neovascularization. We debated at the beginning of the study whether or not to name the atrophy observed as 'geographic atrophy', when we knew that neovascularization had previously resided in the same location. We elected to use the term GA because at the end of two years, the clinical appearance was indistinguishable from the GA that most clinicians historically think of as arising in dry AMD. The fact that the growth rate in our patients with neovascular AMD was so similar to that reported in nonneovascular AMD suggests that there may be some commonality between these lesions.

Most of the incident GA in CATT developed within or in close proximity to the total CNV lesion. Only 15 cases of incident GA had individual GA lesions that were clearly outside of the total CNV lesion. Whether GA that develops within or in close proximity to the total CNV lesion may be histologically different from GA that develops away from the total CNV lesion is not known. We measured whether these two types of GA have different growth rates and we found that GA developing within or in close proximity to the total CNV lesion grows at a faster rate $(0.29 \mathrm{~mm} / \mathrm{year})$ than GA that is clearly away from the total CNV lesion $(0.20 \mathrm{~mm} / \mathrm{year})$ but the difference was of borderline significance $(\mathrm{p}=0.06)$, and therefore, no strong conclusions can be reached. A report of McLeod et $\mathrm{al}^{27}$ showing drop out of choriocapillaries in areas adjacent to CNV could explain a higher yearly growth of GA associated or in close proximity to $\mathrm{CNV}$.

Because the CATT study did not include a placebo treatment arm, we cannot determine whether anti-VEGF therapy has an effect on GA growth that is different from the natural history of GA developing in eyes with exudative AMD. However, there did appear to be a relative difference between drugs with a higher rate of GA growth observed in eyes treated with ranibizumab as compared to bevacizumab. This evidence, together with our previous finding that ranibizumab is associated with a $43 \%$ increased risk of GA development in comparison to bevacizumab, ${ }^{11}$ suggests that ranibizumab may have a stronger effect on GA formation. Studies performed in mice have shown that anti-VEGF treatment can interfere with the maintenance of the ocular vasculature, ${ }^{28}$ and may be associated with retinal pigment epithelial and choroidal atrophy. ${ }^{29,30}$ Therefore, it is possible that these medications that block the effects of VEGF may play a role in the development of GA. The 
differences in the incidence of GA between the two medications could be due to differences in their effects on the RPE and choroid or could be due to the fact that eyes treated with ranibizumab had more complete resolution of fluid. ${ }^{6,8}$

Some what surprisingly, our results did not show any significant difference in GA growth between monthly-treated and PRN-treated subjects. In our previous report, we found that two years of monthly treatment was associated with a 59\% increase in GA incidence in comparison with PRN treatment. ${ }^{11}$ Monthly treatment may be associated with higher GA incidence but once the GA develops the growth rate is not significantly different from that observed in the PRN group. Two genetic studies that have recently shown that certain single nucleotide polymorphisms can affect the incidence of AMD pathologic features but not necessarily affect the progression of these features ${ }^{23,24}$ are consistent with our findings.

Number of injections shows a similar pattern. Although a higher number of injections was associated with increased risk of GA development in our previous report ${ }^{11}$, once the GA developed the growth rate was not significantly associated with number of injections.

In our previous report on the incidence of GA in CATT, we found no significant association between the type of $\mathrm{CNV}$ and newly occurring GA. ${ }^{11}$ However, our current analyses show that once GA develops, eyes that were enrolled with predominantly classic CNV lesions had an almost doubled rate of GA growth rate when compared with eyes with occult CNV lesions. This may be related to the anatomic position of the CNV in relation to the RPE, or perhaps to a more deleterious effect of classic $\mathrm{CNV}$ on the anatomy and function of the retina.

Although epiretinal membrane at baseline was not a significant risk factor for incidence of $\mathrm{GA}$, as reported in our previous report ${ }^{11}$, the presence of epiretinal membrane in our current study was significantly associated with faster GA growth once GA developed. The significance of this finding is not clear but it is possible that epiretinal membranes may alter the anatomy of the retina in a way that may affect the diffusion of substances through the retina resulting in a faster growth of GA.

In summary, our study describes a number of risk factors associated with faster GA growth in AMD patients treated with anti-VEGF medications for two years. These factors were treatment with ranibizumab, female sex, further distance from the fovea, extrafoveal location of $\mathrm{CNV}$, predominantly classic $\mathrm{CNV}, \mathrm{GA}$ in the fellow eye, and epiretinal membrane. Although at two years the effects of ranibizumab and bevacizumab are similar on visual acuity, the longer term effects of these treatments on vision need to be studied. In our study only $12 \%$ of GA was located in the foveal center, and this may partly explain why the visual acuity is not greatly affected. However, because GA lesions grow over time, the long term effect of these treatments on central visual acuity needs to be ascertained beyond two years.

\section{Supplementary Material}

Refer to Web version on PubMed Central for supplementary material. 


\section{Acknowledgments}

Financial Support: This study was supported by cooperative agreements U10 EY017823, U10 EY017825, U10 EY017826, and U10 EY017828 from the National Eye Institute, National Institutes of Health, Department of Health and Human Services. ClinicalTrials.gov number, NCT00593450

\section{References}

1. Friedman DS, O'Colmain BJ, Muñoz B, et al. Eye Diseases Prevalence Research Group. Prevalence of age-related macular degeneration in the United States. Arch Ophthalmol. 2004; 122:564-572. [PubMed: 15078675]

2. Rosenfeld PJ, Brown DM, Heier JS, et al. Ranibizumab for neovascular age-related macular degeneration. N Engl J Med. 2006; 355:1419-1431. [PubMed: 17021318]

3. Brown DM, Kaiser PK, Michels M, et al. Ranibizumab versus verteporfin for neovascular agerelated macular degeneration. N Engl J Med. 2006; 355:1432-1444. [PubMed: 17021319]

4. Rosenfeld PJ, Moshfeghi AA, Puliafito CA. Optical coherence tomography after an intravitreal injection of bevacizumab (Avastin) for neovascular age-related macular degeneration. Ophthalmic Surg Lasers Imaging. 2005; 36:331-335. [PubMed: 16156152]

5. Avery RL, Pieramici DJ, Rabena MD, et al. Intravitreal bevacizumab (Avastin) for neovascular agerelated macular degeneration. Ophthalmology. 2006; 113:363-372. [PubMed: 16458968]

6. Martin DF, Maguire MG, Ying GS, et al. CATT Research Group. Ranibizumab and bevacizumab for neovascular age-related macular degeneration. N Engl J Med. 2011; 364:1897-1908. [PubMed: 21526923]

7. Rosenfeld PJ, Shapiro H, Tuomi L, et al. MARINA and ANCHOR Study Groups. Characteristics of patients losing vision after 2 years of monthly dosing in the phase III ranibizumab clinical trials. Ophthalmology. 2011; 118:523-530. [PubMed: 20920825]

8. The CATT Research Group. Ranibizumab and bevacizumab for treatment of neovascular agerelated macular degeneration: 2-year results. Ophthalmology. 2012; 119:1388-1398. [PubMed: 22555112]

9. Grunwald JE, Daniel E, Ying GS, et al. CATT Research Group. Photographic assessment of baseline fundus morphologic features in the Comparison of Age-Related Macular Degeneration Treatments Trials. Ophthalmology. 2012; 119:1634-1641. [PubMed: 22512984]

10. Jaffe GJ, Martin DF, Toth CA, et al. The CATT Research Group. Macular morphology and visual acuity in the Comparison of Age-related Macular Degeneration Treatments Trials (CATT). Ophthalmology. (In press). Epub 2013 May 03.

11. Grunwald JE, Daniel E, Huang J, et al. The CATT Research Group. Risk factors for the development of GA in CATT. Ophthalmology.

12. Rasband, WS. Image J, U. S. National Institutes of Health. Bethesda, Maryland: USA; 1997-2014. http://imagej.nih.gov/ij/

13. DeCroos FC, Toth CA, Stinnett SS, et al. for the CATT Research Group. Optical coherence tomography grading reproducibility during the Comparison of Age-Related Macular Degeneration Treatments Trials. Ophthalmology. 2012; 119:2549-2557. [PubMed: 22939114]

14. Hagstrom SA, Ying G-S, Pauer GJT, et al. The CATT Research Group. Pharmacogenetics for genes associated with age-related macular degeneration (AMD) in the Comparison of AMD Treatments Trials (CATT). Ophthalmology. 2013; 120:593-599. [PubMed: 23337555]

15. Reynolds R, Rosner B, Seddon JM. Dietary Omega-3 fatty acids, other fat intake, genetic susceptibility, and progression to incident geographic atrophy. Ophthalmology. 2013; 120:10201028. [PubMed: 23481534]

16. Yang Z, Stratton C, Francis PJ, et al. Toll-like Receptor 3 and Geographic Atrophy in Age-Related Macular Degeneration. N Engl J Med. 2008; 359:1456-1463. [PubMed: 18753640]

17. Feuer WJ, Yehoshua Z, Gregori G, et al. Square Root Transformation of Geographic Atrophy Area Measurements to Eliminate Dependence of Growth Rates on Baseline Lesion Measurements: A Reanalysis of Age-Related Eye Disease Study Report No 26. Jama Ophthalmol. 2013; 131:101102. 
18. Domalpally A, Danis RP, White J, et al. Circularity Index as a Risk Factor for Progression of Geographic Atrophy. Ophthalmol. 2013; 120:2666-2671.

19. Yehoshua Z, Filho CA, Nunes RP, et al. Systemic Complement Inhibition with Eculizumab Geographic Atrophy in Age-Related Macular Degeneration. The COMPLETE Study. Ophthalmology. 2014; 121:693-701. [PubMed: 24289920]

20. Joachim N, Mitchell P, Kifley A, et al. Incidence and progression of geographic atrophy: observations from a population-based cohort. Ophthalmol. 2013; 120(10):2042-2050.

21. Klein R, Meuer SM, Knudtson MD, Klein BE. The epidemiology of progression of pure geographic atrophy: the Beaver Dam Eye Study. Am J Ophthalmol. 2008; 146(5):692-699. [PubMed: 18672224]

22. Lindblad AS, Lloyd PC, Clemons TE, et al. Age-Related Eye Disease Study Research Group. Change in area of geographic atrophy in the Age-Related Eye Disease Study: AREDS report number 26. Arch Ophthalmol. 2009; 127(9):1168-1174. [PubMed: 19752426]

23. Caire J, Recalde S, Velazquez-Villoria A, et al. for the Spanish Multicenter Group on AMD. Growth of Geographic Atrophy on Fundus Autofluorescence and Polymorphisms of CFH, CFB, C3, FHR1-3, and ARMS2 in Age-Related Macular Degeneration. JAMA Ophthalmol. 2014; 132(5):528-534. [PubMed: 24557084]

24. Scholl HPN, Fleckenstein M, Fritsche LG, et al. CFH, C3 and ARMS2 Are Significant Risk Loci for Susceptibility but Not for Disease Progression of Geographic Atrophy Due to AMD. PLoS ONE. 2009; 4(10):e7418. [PubMed: 19823576]

25. Sunness JS1, Margalit E, Srikumaran D, et al. The long-term natural history of geographic atrophy from age-related macular degeneration: enlargement of atrophy and implications for interventional clinical trials. Ophthalmol. 2007; 114(2):271-277.

26. Mauschitz MM, Fonseca S, Chang P, et al. GAP Study Group. Topography of geographic atrophy in age-related macular degeneration. Invest Ophthalmol Vis Sci. 2012; 53:4932-4939. [PubMed: 22661483]

27. McLeod DS, Grebe R, Bhutto I, et al. Relationship between RPE and Choriocapillaris in AgeRelated Macular Degeneration. Invest Ophthalmol Vis Sci. 2009; 50:4982-4991. [PubMed: 19357355]

28. Saint-Geniez M, Kurihara T, Sekiyama E, et al. An essential role for RPE-derived soluble VEGF in the maintenance of the choriocapillaris. Proc Natl Acad Sci USA. 2009; 106(44):18751-18756. [PubMed: 19841260]

29. Lois N, Mcbain V, Abdelkader E, et al. Retinal pigment epithelial atrophy in patients with exudative age-related macular degeneration undergoing anti-vascular endothelial growth factor therapy. Retina. 2013; 33:13-22. [PubMed: 22846802]

30. Young M, Chui L, Fallah N, et al. Exacerbation of choroidal and retinal piment epithelial atrophy after anti-vascular endothelial growth factor treatment in neovascular age-related macular degeneration. Retina. 2014; 34:1308-1315. 3. [PubMed: 24451923]

\section{Credit Roster for the Comparison of AMD Treatments Trials Clinical Centers (Ordered by Number of Patients Enrolled)}

Certified Roles at Clinical Centers: Clinic Coordinator (CC), Data Entry Staff (DE), Participating Ophthalmologist (O), Ophthalmic Photographer (OP); Optical Coherent Tomography Technician (OCT), Principal Investigator (PI), Refractionist (R), Visual Acuity Examiner (VA)

VitreoRetinal Surgery, PA (Edina, MN): David F. Williams, MD (PI); Sara Beardsley, COA (VA/R); Steven Bennett, MD (O); Herbert Cantrill, MD (O); Carmen Chan-Tram, COA (VA/R); Holly Cheshier, CRA, COT, OCTC (OP); Kathyrn Damato, COT (VA); John Davies, MD (O); Sundeep Dev, MD (O); Julianne Enloe, CCRP, COA (CC); Gennaro 
Follano (OP/OCT); Peggy Gilbert, COA (VA/R); Jill Johnson, MD (O); Tori Jones, COA (OCT); Lisa Mayleben, COMT (CC/VA/R/OCT); Robert Mittra, MD (O); Martha Moos, COMT, OSA (VA/R); Ryan Neist, COMT (VA/R); Neal Oestreich, COT (CC); Polly Quiram, MD (O); Robert Ramsay, MD (O); Edwin Ryan, MD (O); Stephanie Schindeldecker, OA (VA/R); John Snater, COA (VA); Trenise Steele, COA (VA); Dwight Selders, COA (VA/R); Jessica Tonsfeldt, AO (OP/OCT); Shelly Valardi, COT (VA/R).

Texas Retina Associates (Dallas, TX): Gary Edd Fish, MD (PI); Hank A. Aguado, CRA (OP/OCT); Sally Arceneaux (CC/VA/R); Jean Arnwine (CC); Kim Bell, COA (VA/R); Tina Bell (CC/OCT); Bob Boleman (OP); Patricia Bradley, COT (CC); David Callanan, MD (O); Lori Coors, MD (O); Jodi Creighton, COA (VA/R); Timothy Crew, COA (OCT); Kimberly Cummings (OP/OCT); Christopher Dock (OCT); Karen Duignan, COT (VA/R); Dwain Fuller, MD (O); Keith Gray (OP/OCT); Betsy Hendrix, COT, ROUB (OCT); Nicholas Hesse (OCT); Diana Jaramillo, COA (OCT); Bradley Jost, MD (O); Sandy Lash (VA/R); Laura Lonsdale, CCRP (DE); Michael Mackens (OP/OCT); Karin Mutz, COA (CC); Michael Potts (VA/R); Brenda Sanchez (VA/R); William Snyder, MD (O); Wayne Solley, MD (O); Carrie Tarter (VA/R); Robert Wang, MD (O); Patrick Williams, MD (O).

Southeastern Retina Associates (Knoxville, TN): Stephen L. Perkins, MD (PI); Nicholas Anderson, MD (O); Ann Arnold, COT (VA/R); Paul Blais (OP/OCT); Joseph Googe, MD (O); Tina T. Higdon, (CC); Cecile Hunt (VA/R); Mary Johnson, COA (VA/R); James Miller, MD (O); Misty Moore (VA/R); Charity K. Morris, RN (CC); Christopher Morris (OP/OCT); Sarah Oelrich, COT (OP/OCT); Kristina Oliver, COA (VA/R); Vicky Seitz, COT (VA/R); Jerry Whetstone (OP/OCT).

Retina Vitreous Consultants (Pittsburgh, PA): Bernard H. Doft (PI); Jay Bedel, RN, (CC); Robert Bergren, MD (O); Ann Borthwick (VA/R); Paul Conrad, MD, PHD (O); Amanda Fec (OCT); Christina Fulwylie (VA/R); Willia Ingram (DE); Shawnique Latham (VA/R); Gina Lester (VA/R); Judy Liu, MD (O); Louis Lobes, MD (O); Nicole M. Lucko, (CC); Holly Mechling (CC); Lori Merlotti, MS, CCRC (CC); Keith McBroom (OCT); Karl Olsen, MD (O); Danielle Puskas, COA (VA/R); Pamela Rath, MD (O); Maria Schmucker (CC); Lynn Schueckler (OCT); Christina Schultz (CC/VA/R); Heather Shultz (OP/OCT); David Steinberg, CRA (OP/OCT); Avni Vyas, MD (O); Kim Whale (VA/R); Kimberly Yeckel, COA, COT (VA/R).

Ingalls Memorial Hospital/Illinois Retina Associates (Harvey, IL): David H. Orth, MD (PI); Linda S. Arredondo, RN (CC/VA); Susan Brown (VA/R); Barbara J. Ciscato (CC/VA); Joseph M. Civantos, MD (O); Celeste Figliulo (VA/R); Sohail Hasan, MD (O); Belinda Kosinski, COA (VA/R); Dan Muir (OP/OCT); Kiersten Nelson (OP/OCT); Kirk Packo, MD (O); John S. Pollack, MD (O); Kourous Rezaei, MD (O); Gina Shelton (VA); Shannya Townsend-Patrick (OP/OCT); Marian Walsh, CRA (OP/OCT).

West Coast Retina Medical Group, Inc. (San Francisco, CA): H. Richard McDonald, MD (PI); Nina Ansari (VA/R/OCT); Amanda Bye, (OP/OCT); Arthur D. Fu, MD (O); Sean Grout (OP/OCT); Chad Indermill (OCT); Robert N. Johnson, MD (O); J. Michael Jumper, MD (O); Silvia Linares (VA/R); Brandon J. Lujan, MD (O); Ames Munden (OP/OCT); 
Meredith Persons (CC); Rosa Rodriguez (CC); Jennifer M. Rose (CC); Brandi Teske, COA (VA/R); Yesmin Urias (OCT); Stephen Young (OP/OCT).

Retina Northwest, P.C. (Portland, OR): Richard F. Dreyer, MD (PI); Howard Daniel (OP/ OCT); Michele Connaughton, CRA (OP/OCT); Irvin Handelman, MD (O); Stephen Hobbs (VA/R/OCT); Christine Hoerner (OP/OCT); Dawn Hudson (VA/R/OCT); Marcia Kopfer, COT (CC/VA/R/OCT); Michael Lee, MD (O); Craig Lemley, MD (O); Joe Logan, COA (OP/OCT); Colin Ma, MD (O); Christophe Mallet (VA/R); Amanda Milliron (VA/R); Mark Peters, MD (O); Harry Wohlsein, COA (OP).

Retinal Consultants Medical Group, Inc. (Sacramento, CA): Joel A. Pearlman, MD, PHD (PI); Margo Andrews (OP/OCT); Melissa Bartlett (OCT); Nanette Carlson (CC/OCT); Emily Cox (VA/R); Robert Equi, MD (O); Marta Gonzalez (VA/R/OCT); Sophia Griffin (OP/OCT); Fran Hogue (VA/R); Lance Kennedy (OP/OCT); Lana Kryuchkov (OCT); Carmen Lopez (VA/R); Danny Lopez (OP/OCT); Bertha Luevano (VA/R); Erin McKenna, (CC); Arun Patel, MD (O); Brian Reed, MD (O); Nyla Secor (CC/OCT); Iris R. Sison (CC); Tony Tsai, MD (O); Nina Varghis, (CC); Brooke Waller (OCT); Robert Wendel, MD (O); Reina Yebra (OCT).

Retina Vitreous Center, PA (New Brunswick, NJ): Daniel B. Roth, MD (PI); Jane Deinzer, RN (CC/VA/R); Howard Fine, MD MHSC (O); Flory Green (VA/R); Stuart Green, MD (O); Bruce Keyser, MD (O); Steven Leff, MD (O); Amy Leviton (VA/R); Amy Martir (OCT); Kristin Mosenthine (VA/R/OCT); Starr Muscle, RN (CC); Linda Okoren (VA/R); Sandy Parker (VA/R); Jonathan Prenner, MD (O); Nancy Price (CC); Deana Rogers (OP/ OCT); Linda Rosas (OP/OCT); Alex Schlosser (OP/OCT); Loretta Studenko (DE); Thea Tantum (CC); Harold Wheatley, MD (O).

Vision Research Foundation/Associated Retinal Consultants, P.C. (Royal Oak, MI): Michael T. Trese, MD (PI); Thomas Aaberg, MD (O); Tina Bell (VA/R/OP/OCT); Denis Bezaire, CRA (OP/OCT); Craig Bridges, CRA (OP/OCT); Doug Bryant, CRA (OP/OCT); Antonio Capone, MD (O); Michelle Coleman, RN (CC); Christina Consolo, CRA, COT (OP/OCT); Cindy Cook, RN (CC); Candice DuLong (VA/R); Bruce Garretson, MD (O); Tracy Grooten (VA/R); Julie Hammersley, RN (CC); Tarek Hassan, MD (O); Heather Jessick (OP/OCT); Nanette Jones (VA/R/OP/OCT); Crystal Kinsman (VA/R); Jennifer Krumlauf (VA/R); Sandy Lewis, COT (VA/R/OP/OCT); Heather Locke (VA/R); Alan Margherio, MD (O); Debra Markus, COT (CC/VA/R/OP/OCT); Tanya Marsh, COA (OP/ OCT); Serena Neal (CC); Amy Noffke, MD (O); Kean Oh, MD (O); Clarence Pence (OP/ OCT); Lisa Preston (VA/R); Paul Raphaelian, MD (O); Virginia R. Regan, RN, CCRP (VA/R); Peter Roberts (OP/OCT); Alan Ruby, MD (O); Ramin Sarrafizadeh, MD, PHD (O); Marissa Scherf (OP/OCT); Sarita Scott (VA/R); Scott Sneed, MD (O); Lisa Staples (CC); Brad Terry (VA/R/OP/OCT); Matthew T. Trese (OCT); Joan Videtich, RN (VA/R); George Williams, MD (O); Mary Zajechowski, COT, CCRC (CC/VA/R).

Barnes Retina Institute (St. Louis, MO): Daniel P. Joseph, MD (PI); Kevin Blinder, MD (O); Lynda Boyd, COT (VA/R); Sarah Buckley (OP/OCT); Meaghan Crow (VA/R); Amanda Dinatale, (OCT); Nicholas Engelbrecht, MD (O); Bridget Forke (OP/OCT); Dana 
Gabel (OP/OCT); Gilbert Grand, MD (O); Jennifer Grillion-Cerone (VA/R); Nancy Holekamp, MD (O); Charlotte Kelly, COA (VA/R); Ginny Nobel, COT (CC); Kelly Pepple (VA/R); Matt Raeber, (OP/OCT); P. Kumar Rao, MD (O); Tammy Ressel, COT (VA/R); Steven Schremp (OCT); Merrilee Sgorlon (VA/R); Shantia Shears, MA (CC); Matthew Thomas, MD (O); Cathy Timma (VA/R); Annette Vaughn,(OP/OCT); Carolyn Walters, COT (CC/VA/R); Rhonda Weeks, CRC (CC/VA/R); Jarrod Wehmeier (OP/OCT); Tim Wright (OCT).

The Retina Group of Washington (Chevy Chase, MD): Daniel M. Berinstein, MD (PI); Aida Ayyad (VA/R); Mohammed K. Barazi, MD (O); Erica Bickhart (CC/VA/R); Tracey Brady (OCT); Lisa Byank, MA (CC); Alysia Cronise, COA (VA/R); Vanessa Denny (VA/R); Courtney Dunn (VA/R); Michael Flory (OP/OCT); Robert Frantz (OP/OCT); Richard A. Garfinkel, MD (O); William Gilbert, MD (O); Michael M. Lai, MD, PHD (O); Alexander Melamud, MD (O); Janine Newgen (VA/R); Shamekia Newton (CC); Debbie Oliver (CC); Michael Osman, MD (O); Reginald Sanders, MD (O); Manfred von Fricken, $\mathrm{MD}(\mathrm{O})$.

Retinal Consultants of Arizona (Phoenix, AZ): Pravin Dugel, MD (PI); Sandra Arenas (CC); Gabe Balea (OCT); Dayna Bartoli (OP/OCT); John Bucci (OP/OCT); Jennifer A. Cornelius (CC); Scheleen Dickens, (CC); Don Doherty (OP/OCT); Heather Dunlap, COA (VA/R); David Goldenberg, MD (O); Karim Jamal, MD (O); Norma Jimenez (OP/OCT); Nicole Kavanagh (VA/R); Derek Kunimoto, MD (O); John Martin (OP/OCT); Jessica Miner, RN (VA/R); Sarah Mobley, CCRC (CC/VA/R); Donald Park, MD (O); Edward Quinlan, MD (O); Jack Sipperley, MD (O); Carol Slagle (R); Danielle Smith (OP/OCT); Miguelina Yafchak (OCT); Rohana Yager, COA (OP/OCT).

Casey Eye Institute (Portland, OR): Christina J. Flaxel, MD (PI); Steven Bailey, MD (O); Peter Francis, MD, PHD (O); Chris Howell, (OCT); Thomas Hwang, MD (O); Shirley Ira, COT (VA/R); Michael Klein, MD (O); Andreas Lauer, MD (O); Teresa Liesegang, COT (CC/VA/R); Ann Lundquist, (CC/VA/R); Sarah Nolte (DE); Susan K. Nolte (VA/R); Scott Pickell (OP/OCT); Susan Pope, COT (VA/R); Joseph Rossi (OP/OCT); Mitchell Schain (VA/R); Peter Steinkamp, MS (OP/OCT); Maureen D. Toomey (CC/VA/R); Debora Vahrenwald, COT (VA/R); Kelly West (OP/OCT).

Emory Eye Center (Atlanta, GA): Baker Hubbard, MD (PI); Stacey Andelman, MMSC, COMT (CC/VA/R); Chris Bergstrom, MD (O); Judy Brower, COMT (CC/VA/R); Blaine Cribbs, MD (O); Linda Curtis (VA/R); Jannah Dobbs (OP/OCT); Lindreth DuBois, MED, MMSC, CO, COMT (CC/VA/R); Jessica Gaultney (OCT); Deborah Gibbs, COMT, CCRC (VA/R); Debora Jordan, CRA (OP/OCT); Donna Leef, MMSC, COMT (VA/R); Daniel F. Martin, MD (O); Robert Myles, CRA (OP); Timothy Olsen, MD (O); Bryan Schwent, MD (O); Sunil Srivastava, MD (O); Rhonda Waldron, MMSC, COMT, CRA, RDMS (OCT).

Charlotte Eye, Ear, Nose \& Throat Associates/Southeast Clinical Research (Charlotte, NC): Andrew N. Antoszyk, MD (PI); Uma Balasubramaniam, COA (OCT); Danielle Brooks, CCRP (VA/R); Justin Brown, MD (O); David Browning, MD, PHD (O); Loraine Clark, COA (OP/OCT); Sarah Ennis, CCRC (VA/R); Susannah Held (OCT); Jennifer V. 
Helms, CCRC,(CC); Jenna Herby, CCRC (CC); Angie Karow, CCRP (VA/R); Pearl Leotaud, CRA (OP/OCT); Caterina Massimino (OCT); Donna McClain, COA (OP/OCT); Michael McOwen, CRA (OP/OCT); Jennifer Mindel, CRA, COA (OP/OCT); Candace Pereira, CRC (CC); Rachel Pierce, COA (VA/R); Michele Powers (OP/OCT); Angela Price, MPH, CCRC (CC); Jason Rohrer (CC); Jason Sanders, MD (O).

California Retina Consultants (Santa Barbara, CA): Robert L. Avery, MD (PI); Kelly Avery (VA/R); Jessica Basefsky (CC/OCT); Liz Beckner (OP); Alessandro Castellarin, MD (O); Stephen Couvillion, MD (O); Jack Giust (CC/OCT); Matthew Giust (OP); Maan Nasir, MD (O); Dante Pieramici, MD (O); Melvin Rabena (VA/R); Sarah Risard (VA/R/OCT/DE); Robert See, MD (O); Jerry Smith (VA/R); Lisha Wan (VA/R).

Mayo Clinic (Rochester, MN): Sophie J. Bakri, MD (PI); Nakhleh Abu-Yaghi, MD (O); Andrew Barkmeier, MD (O); Karin Berg, COA (VA/R); Jean Burrington, COA (VA/R); Albert Edwards, MD (O); Shannon Goddard, COA (OP/OCT); Shannon Howard (VA/R); Raymond Iezzi, MD (O); Denise Lewison, COA (OP/OCT); Thomas Link, CRA (OP/OCT); Colin A. McCannel, MD (O); Joan Overend (VA/R); John Pach, MD (O); Margaret Ruszczyk, CCRP (CC); Ryan Shultz, MD (O); Cindy Stephan, COT (VA/R); Diane Vogen (CC).

Dean A. McGee Eye Institute (Oklahoma City, OK): Reagan H. Bradford Jr, MD (PI); Vanessa Bergman, COA, CCRC (CC); Russ Burris (OP/OCT); Amanda Butt, CRA (OP/ OCT); Beth Daniels, COA (CC); Connie Dwiggins, CCRC (CC); Stephen Fransen, MD (O); Tiffany Guerrero (CC/DE); Darin Haivala, MD (O); Amy Harris (CC); Sonny Icks (CC/ $\mathrm{DE}$ ); Ronald Kingsley, MD (O); Lena Redden (VA/R); Rob Richmond (OP/OCT); Brittany Ross (VA/R); Kammerin White, CCRC (VA/R); Misty Youngberg, COA, CCRC (VA/R).

Ophthalmic Consultants of Boston (Boston, MA): Trexler M. Topping, MD (PI); Steve Bennett (OCT); Sandy Chong (VA/R); Mary Ciotti, COA (CC); Tina Cleary, MD (O); Emily Corey (VA/R); Dennis Donovan (OP/OCT); Albert Frederick, MD (O); Lesley Freese (CC/VA/R); Margaret Graham (OP/OCT); Natalya Gud, COA (VA/R); Taneika Howard (VA/R); Mike Jones (OP/OCT); Michael Morley, MD (O); Katie Moses (VA/R); Jen Stone (VA/R); Robin Ty, COA (VA/R); Torsten Wiegand, PHD, MD (O); Lindsey Williams (CC); Beth Winder (CC).

Tennessee Retina, P.C. (Nashville, TN): Carl C. Awh, MD (PI); Michelle Amonette (OCT); Everton Arrindell, MD (O); Dena Beck (OCT); Brandon Busbee, MD (O); Amy Dilback (OP/OCT); Sara Downs (VA/R); Allison Guidry, COA (VA/R); Gary Gutow, MD (O); Jackey Hardin (VA/R); Sarah Hines, COA (CC); Emily Hutchins (VA/R); Kim LaCivita, MA (OP/OCT); Ashley Lester (OP/OCT); Larry Malott (OP/OCT); MaryAnn McCain, RN, CNOR (CC); Jayme Miracle (VA/R); Kenneth Moffat, MD (O); Lacy Palazzotta (VA/R); Kelly Robinson, COA (VA/R); Peter Sonkin, MD (O); Alecia Travis (OP/OCT); Roy Trent Wallace, MD (O); Kelly J. Winters, COA (CC); Julia Wray (OP/ OCT).

Retina Associates Southwest, P.C. (Tucson, AZ): April E. Harris, MD (PI); Mari Bunnell (OCT); Katrina Crooks (VA/R); Rebecca Fitzgerald, CCRC (CC/OCT); Cameron Javid, 
MD (O); Corin Kew (VA/R); Erica Kill, VAE (VA/R); Patricia Kline (VA/R); Janet Kreienkamp (VA/R); Maricruz Martinez (CC/OCT); Roy Ann Moore, OMA (CC/OCT); Egbert Saavedra, MD (O); LuAnne Taylor, CSC (CC/OCT); Mark Walsh, MD (O); Larry Wilson (OP).

Midwest Eye Institute (Indianapolis, IN): Thomas A. Ciulla, MD (PI); Ellen Coyle, COMT (VA/R); Tonya Harrington, COA (VA/R); Charlotte Harris, COA (VA/OCT); Cindi Hood (OCT); Ingrid Kerr, COA (VA/R); Raj Maturi, MD (O); Dawn Moore (OCT); Stephanie Morrow, COA (OP); Jennifer Savage, COA (VA); Bethany Sink, COA (CC/VA/R); Tom Steele, CRA (OP); Neelam Thukral, CCRC (CC/OCT); Janet Wilburn, COA (CC).

National Ophthalmic Research Institute (Fort Myers, FL): Joseph P. Walker, MD (PI); Jennifer Banks (VA/R); Debbie Ciampaglia (OP/OCT); Danielle Dyshanowitz (VA/R); Jennifer Frederick, CRC (CC); A. Tom Ghuman, MD (O); Richard Grodin, MD (O); Cheryl Kiesel, CCRC (CC); Eileen Knips, RN, CCRC, CRA (OP/OCT); Jonathan McCue (VA/R); Maria Ortiz (VA/R); Crystal Peters, CCRC (CC); Paul Raskauskas, MD (O); Etienne Schoeman (OP/OCT); Ashish Sharma, MD (O); Glenn Wing, MD (O), Rebecca Youngblood (CC).

University of Wisconsin Madison (Madison, WI): Suresh R. Chandra, MD (PI); Michael Altaweel, MD (O); Barbara Blodi, MD (O); Kathryn Burke, BA (VA/R); Kristine A. Dietzman, (CC); Justin Gottlieb, MD (O); Gene Knutson (OP/OCT); Denise Krolnik (OP/ OCT); T. Michael Nork, MD (O); Shelly Olson (VA/R); John Peterson, CRA (OP/OCT); Sandra Reed (OP/OCT); Barbara Soderling (VA/R); Guy Somers (VA/R); Thomas Stevens, MD (O); Angela Wealti, (CC).

Duke University Eye Center (Durham, NC): Srilaxmi Bearelly, MD (PI); Brenda Branchaud (VA/R); Joyce W. Bryant, COT, CPT (CC/VA/R); Sara Crowell (CC/VA); Sharon Fekrat, MD (O); Merritt Gammage (OP/OCT); Cheala Harrison, COA (VA/R); Sarah Jones (VA); Noreen McClain, COT, CPT, CCRC (VA/R); Brooks McCuen, MD (O); Prithvi Mruthyunjaya, MD (O); Jeanne Queen, CPT (OP/OCT); Neeru Sarin, MBBS (VA/R); Cindy Skalak, RN, COT (VA/R); Marriner Skelly, CRA (OP/OCT); Ivan Suner, MD (O); Ronnie Tomany (OP/OCT); Lauren Welch (OP/OCT).

University of California-Davis Medical Center (Sacramento, CA): Susanna S. Park, MD, PHD (PI); Allison Cassidy (VA/R); Karishma Chandra (OP/OCT); Idalew Good (VA/R); Katrina Imson (CC); Sashi Kaur (OP/OCT); Helen Metzler, COA, CCRP (CC/VA/R); Lawrence Morse, MD, PHD (O); Ellen Redenbo, ROUB (OP/OCT); Marisa Salvador (VA/R); David Telander, MD (O); Mark Thomas, CRA (OCT); Cindy Wallace, COA (CC).

University of Louisville School of Medicine, KY (Louisville, KY): Charles C. Barr, MD (PI); Amanda Battcher (VA/R); Michelle Bottorff, COA (CC/OCT); Mary Chasteen (VA/R); Kelly Clark (VA/R); Diane Denning, COT (OCT); Debra Schoen (OP); Amy Schultz (OP); Evie Tempel, CRA, COA (OP); Lisa Wheeler, COT (VA/R); Greg K. Whittington, MPS, PSY (CC). 
Retina Associates of Kentucky (Lexington, KY): Thomas W. Stone, MD (PI); Todd Blevins (OP/OCT); Michelle Buck, COT, (VA/R/OCT); Lynn Cruz, COT (CC); Wanda Heath (VA/R); Diana Holcomb (VA/R); Rick Isernhagen, MD (O); Terri Kidd, COA (OCT); John Kitchens, MD (O); Cathy Sears, CST, COA (VA/R); Ed Slade, CRA, COA (OP/OCT); Jeanne Van Arsdall, COA (VA/R); Brenda VanHoose, COA (VA/R); Jenny Wolfe, RN (CC); William Wood, MD (O).

Colorado Retina Associates (Denver, CO): John Zilis, MD (PI); Carol Crooks, COA (VA/R); Larry Disney (VA/R); Mimi Liu, MD (O); Stephen Petty, MD (O); Sandra Sall, ROUB, COA (CC/VA/R/OP/OCT).

University of Iowa Hospitals \& Clinics (Iowa City, IA): James C. Folk, MD (PI); Tracy Aly, CRA (OP/OCT); Abby Brotherton (VA); Douglas Critser, CRA (OP/OCT); Connie J. Hinz, COT, CCRC (CC/VA/R); Stefani Karakas, CRA (OP/OCT); Valerie Kirschner (VA); Cheyanne Lester (VA/R); Cindy Montague, CRA (OP/OCT); Stephen Russell, MD (O); Heather Stockman (VA/R); Barbara Taylor, CCRC (VA/R); Randy Verdick, FOPS (OP/ OCT), Jean Walshire (CC).

Retina Specialists (Towson, MD): John T. Thompson, MD (PI) ; Barbara Connell (VA/R); Maryanth Constantine (CC); John L. Davis Jr (VA/R); Gwen Holsapple (VA/R); Lisa Hunter (OP/OCT); C. Nicki Lenane (CC/VA/R/OP/OCT); Robin Mitchell (CC); Leslie Russel, CRA (OP/OCT); Raymond Sjaarda, MD (O).

Retina Consultants of Houston (Houston, TX): David M. Brown, MD (PI); Matthew Benz, MD (O); Llewellyn Burns (OCT); JoLene G. Carranza, COA, CCRC (CC); Richard Fish, MD (O); Debra Goates (VA/R); Shayla Hay (VA/R); Theresa Jeffers, COT (VA/R); Eric Kegley, CRA, COA (OP/OCT); Dallas Kubecka (VA/R); Stacy McGilvra (VA/R); Beau Richter (OCT); Veronica Sneed, COA (VA/R); Cary Stoever (OCT); Isabell Tellez (VA/R); Tien Wong, MD (O).

Massachusetts Eye and Ear Infirmary/Harvard Vanguard Medical Associates (Boston, MA): Ivana Kim, MD (PI); Christopher Andreoli, MD (O); Leslie Barresi, CRA, COA, OCT-C (VA/OP/OCT); Sarah Brett (OP); Charlene Callahan (OP); Karen Capaccioli (OCT); William Carli, COA (VA/R/OCT); Matthew Coppola, COA (VA); Nicholas Emmanuel (CC); Claudia Evans, OD (VA/R); Anna Fagan, COA (VA/R); Marcia Grillo (OCT); John Head, CRA, OCT-C (OP/OCT); Troy Kieser, COA, OCT-C (CC/VA/R); Elaine Lee, COA (VA); Ursula Lord, OD (VA/R); Edward Miretsky (CC); Kate Palitsch (OP/OCT); Todd Petrin, RN (OCT); Liz Reader (CC); Svetlana Reznichenko, COA (VA); Mary Robertson, COA (VA); Justin Smith, OD (VA/R); Demetrios Vavvas, MD, PHD (O).

Palmetto Retina Center (West Columbia, SC): John Wells, MD (PI); Cassie Cahill (VA/R); W. Lloyd Clark, MD (O); Kayla Henry (VA/R); David Johnson, MD (O); Peggy Miller (CC/VA/R); LaDetrick Oliver, COT (OP/OCT); Robbin Spivey (OP/OCT); Tiffany Swinford (VA/R); Mallie Taylor (CC). 
Retina and Vitreous of Texas (Houston, TX): Michael Lambert, MD (PI); Kris Chase (OP/OCT); Debbie Fredrickson, COA (VA/R); Joseph Khawly, MD, FACS (O); Valerie Lazarte (VA/R); Donald Lowd (OP/OCT); Pam Miller (CC); Arthur Willis, MD (O).

Long Island Vitreoretinal Consultants (Great Neck, NY): Philip J. Ferrone, MD (PI); Miguel Almonte (OCT); Rachel Arnott, (CC); Ingrid Aviles (VA/R/OCT); Sheri Carbon (VA/R); Michael Chitjian (OP/OCT); Kristen DAmore (CC); Christin Elliott (VA/R); David Fastenberg, MD (O); Barry Golub, MD (O); Kenneth Graham, MD (O); AnnMarie Lavorna (CC); Laura Murphy (VA/R); Amanda Palomo (VA/R); Christina Puglisi (VA/R); David Rhee, MD (O); Juan Romero, MD (O); Brett Rosenblatt, MD (O); Glenda Salcedo (OP/ OCT); Marianne Schlameuss, RN (CC); Eric Shakin, MD (O); Vasanti Sookhai (VA/R).

Wills Eye Institute (Philadelphia, PA): Richard Kaiser, MD (PI); Elizabeth Affel, MS, OCT-C (OCT); Gary Brown, MD (O); Christina Centinaro (CC); Deborah Fine, COA (OCT); Mitchell Fineman, MD (O); Michele Formoso (CC); Sunir Garg, MD (O); Lisa Grande (VA/R); Carolyn Herbert (VA/R); Allen Ho, MD (O); Jason Hsu, MD (O); Maryann Jay (OCT); Lisa Lavetsky (OCT); Elaine Liebenbaum (OP); Joseph Maguire, MD (O); Julia Monsonego (OP/OCT); Lucia O'Connor (OCT); Lisa Pierce (CC); Carl Regillo, MD (O); Maria Rosario (DE); Marc Spirn, MD (O); James Vander, MD (O); Jennifer Walsh (VA/R).

Ohio State University Eye Physicians \& Surgeons-Retina Division (Dublin, OH): Frederick H. Davidorf, MD (PI); Amanda Barnett (OP/OCT); Susie Chang, MD (O); John Christoforidis, MD (O); Joy Elliott (CC); Heather Justice (VA/R); Alan Letson, MD (O); Kathryne McKinney, COMT (CC); Jeri Perry, COT (VA/R); Jill A. Salerno, COA (CC); Scott Savage (OP); Stephen Shelley (OCT).

Retina Associates of Cleveland (Beachwood, $\mathbf{O H}$ ): Lawrence J. Singerman, MD (PI);Joseph Coney, MD (O); John DuBois (OP/OCT); Kimberly DuBois, LPN, CCRP, COA (VA/R); Gregg Greanoff, CRA (OP/OCT); Dianne Himmelman, RN, CCRC (CC); Mary Ilc, COT (VA/R); Elizabeth Mcnamara (VA/R/OP); Michael Novak, MD (O); Scott Pendergast, MD (O); Susan Rath, PA-C (CC); Sheila Smith- Brewer, CRA (OP/OCT); Vivian Tanner, COT, CCRP (VA/R); Diane E. Weiss, RN, (CC); Hernando Zegarra, MD (O).

Retina Group of Florida (Fort Lauderdale, FL): Lawrence Halperin, MD (PI); Patricia Aramayo (OCT); Mandeep Dhalla, MD (O); Brian Fernandez, MD (OP/OCT); Cindy Fernandez, MD (CC); Jaclyn Lopez (CC); Monica Lopez (OCT); Jamie Mariano, COA (VA/R); Kellie Murphy, COA (OCT); Clifford Sherley, COA (VA/R); Rita Veksler, COA (OP/OCT).

Retina-Vitreous Associates Medical Group (Beverly Hills, CA): Firas Rahhal, MD (PI); Razmig Babikian (DE); David Boyer, MD (O); Sepideh Hami (DE); Jeff Kessinger (OP/ OCT); Janet Kurokouchi (CC); Saba Mukarram (VA/R); Sarah Pachman (VA/R); Eric Protacio (OCT); Julio Sierra (VA/R); Homayoun Tabandeh, MD, MS, FRCP (O); Adam Zamboni (VA/R).

Elman Retina Group, P.A. (Baltimore, MD): Michael Elman, MD (PI); Jennifer Belz (CC); Tammy Butcher (CC); Theresa Cain (OP/OCT); Teresa Coffey, COA (VA/R); Dena 
Firestone (VA/R); Nancy Gore (VA/R); Pamela Singletary (VA/R); Peter Sotirakos (OP/ OCT); JoAnn Starr (CC).

University of North Carolina at Chapel Hill (Chapel Hill, NC): Travis A. Meredith, MD (PI); Cassandra J. Barnhart, MPH (CC/VA/R); Debra Cantrell, COA (VA/R/OP/OCT); RonaLyn Esquejo- Leon (OP/OCT); Odette Houghton, MD (O); Harpreet Kaur (VA/R); Fatoumatta NDure, COA (CC).

Ophthalmologists Enrolling Patients but No Longer Affiliated with a CATT Center: Ronald Glatzer, MD (O); Leonard Joffe, MD (O); Reid Schindler, MD (O).

\section{Resource Centers}

Chairman's Office (Cleveland Clinic, Cleveland, OH): Daniel F. Martin, MD (Chair); Stuart L. Fine, MD (Vice-Chair; University of Colorado, Denver, CO); Marilyn Katz (Executive Assistant).

Coordinating Center (University of Pennsylvania, Philadelphia, PA): Maureen G. Maguire, PhD (PI); Mary Brightwell-Arnold, SCP (Systems Analyst); Ruchira Glaser, MD (Medical Monitor); Judith Hall (Protocol Monitor); Sandra Harkins (Staff Assistant); Jiayan Huang, MS (Biostatistician); Alexander Khvatov, MS (Systems Analyst); Kathy McWilliams, CCRP (Protocol Monitor); Susan K. Nolte (Protocol Monitor); Ellen Peskin, MA, CCRP (Project Director); Maxwell Pistilli, MS, MEd (Biostatistician); Susan Ryan (Financial Administrator); Allison Schnader (Administrative Coordinator); Gui-Shuang Ying, $\mathrm{PhD}$ (Senior Biostatistician).

OCT Reading Center (Duke University, Durham, NC): Glenn Jaffe, MD (PI); Jennifer Afrani-Sakyi (CATT PowerPoint Presentations); Brannon Balsley (OCT Technician Certifications); Linda S. Bennett (Project Manager); Adam Brooks (Reader/SD-Reader); Adrienne Brower-Lingsch (Reader); Lori Bruce (Data Verification); Russell Burns (Senior Technical Analyst/Senior Reader/SD Reader/OCT Technician Certifications); Dee Busian (Reader); John Choong (Reader); Lindsey Cloaninger (Reader Reliability Studies/ Document Creation/CATT PPT Files); Francis Char DeCroos (Research Associate); Emily DuBois (Data Entry); Mays El-Dairi (Reader/SD-Reader); Sarah Gach (Reader); Katelyn Hall (Project Manager/Reader Reliability Studies/ Data Verification/Document Creation); Terry Hawks (Reader); ChengChenh Huang (Reader); Cindy Heydary (Senior Reader/ Quality Assurance Coordinator/SD Reader/Data Verification); Alexander Ho (Reader, Transcription); Shashi Kini (Data Entry/Transcription); Michelle McCall (Data Verification); Daaimah Muhammad (Reader Feedback); Jayne Nicholson (Data Verification); Jeanne Queen (Reader/SD-Reader); Pamela Rieves (Transcription); Kelly Shields (Senior Reader); Cindy Skalak (Reader); Adam Specker (Reader); Sandra Stinnett (Biostatistician); Sujatha Subramaniam (Reader); Patrick Tenbrink (Reader); Cynthia Toth, MD (Director of Grading); Aaron Towe (Reader); Kimberly Welch (Data Verification); Natasha Williams (Data Verification); Katrina Winter (Senior Reader); Ellen Young (Senior Project Manager). 
Fundus Photograph Reading Center (University of Pennsylvania, Philadelphia, PA): Juan E. Grunwald, MD (PI); Judith Alexander (Director); Ebenezer Daniel, MBBS, MS, MPH, PhD (Director); Elisabeth Flannagan (Administrative Coordinator); E. Revell Martin (Reader); Candace Parker (Reader); Krista Sepielli (Reader); Tom Shannon (Systems Analyst); Claressa Whearry (Data Coordinator).

National Eye Institute, National Institutes of Health: Maryann Redford, DDS, MPH (Program Officer).

\section{Committees}

Executive Committee: Daniel F. Martin, MD (chair); Robert L. Avery, MD; Sophie J. Bakri, MD; Ebenezer Daniel, MBBS, MS, MPH; Stuart L. Fine, MD; Juan E. Grunwald, MD; Glenn Jaffe, MD, Marcia R. Kopfer, BS, COT; Maureen G. Maguire, PhD; Travis A. Meredith, MD; Ellen Peskin, MA, CCRP; Maryann Redford, DDS, MPH; David F. Williams, MD.

Operations Committee: Daniel F. Martin, MD (chair); Linda S. Bennett; Ebenezer Daniel, MBBS, MS, MPH; Frederick L. Ferris III, MD; Stuart L. Fine, MD; Juan E. Grunwald, MD; Glenn Jaffe, MD; Maureen G. Maguire, PhD; Ellen Peskin, MA, CCRP; Maryann Redford, DDS, MPH; Cynthia Toth, MD.

Clinic Monitoring Committee: Ellen Peskin, MA, CCRP (chair); Mary Brightwell-Arnold, SCP; Joan DuPont; Maureen G. Maguire, PhD; Kathy McWilliams, CCRP; Susan K. Nolte.

Data and Safety Monitoring Committee: Lawrence M. Friedman, MD (chair); Susan B. Bressler, MD; David L. DeMets, PhD; Martin Friedlander, MD, PhD; Mark W. Johnson, MD; Anne Lindblad, PhD; Douglas W. Losordo, MD, FACC; Franklin G. Miller, PhD. 


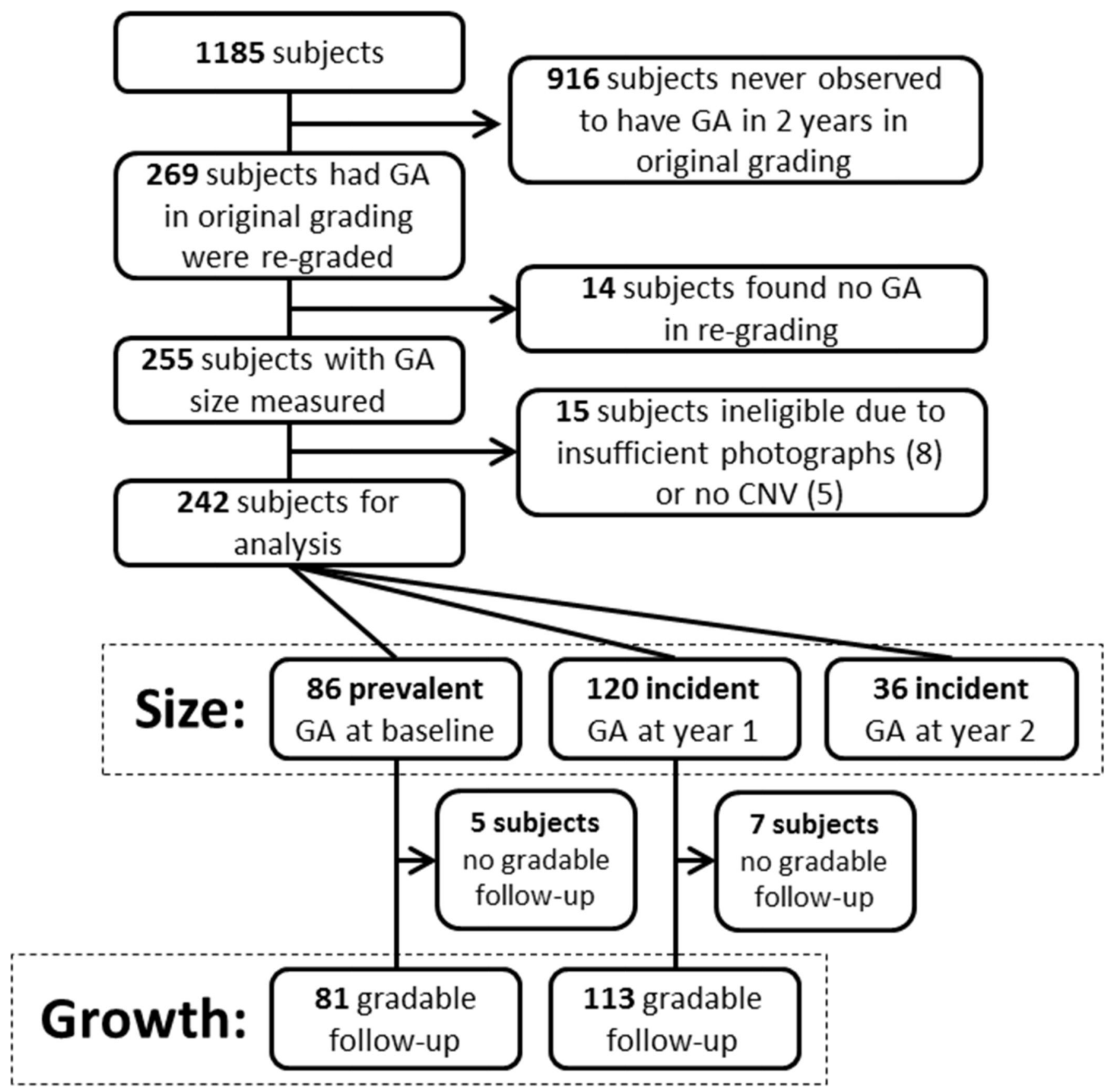

Figure 1.

Flow chart describing the patients of the study. $\mathrm{GA}=$ geographic atrophy, $\mathrm{CNV}=$ choroidal neovascularization. 


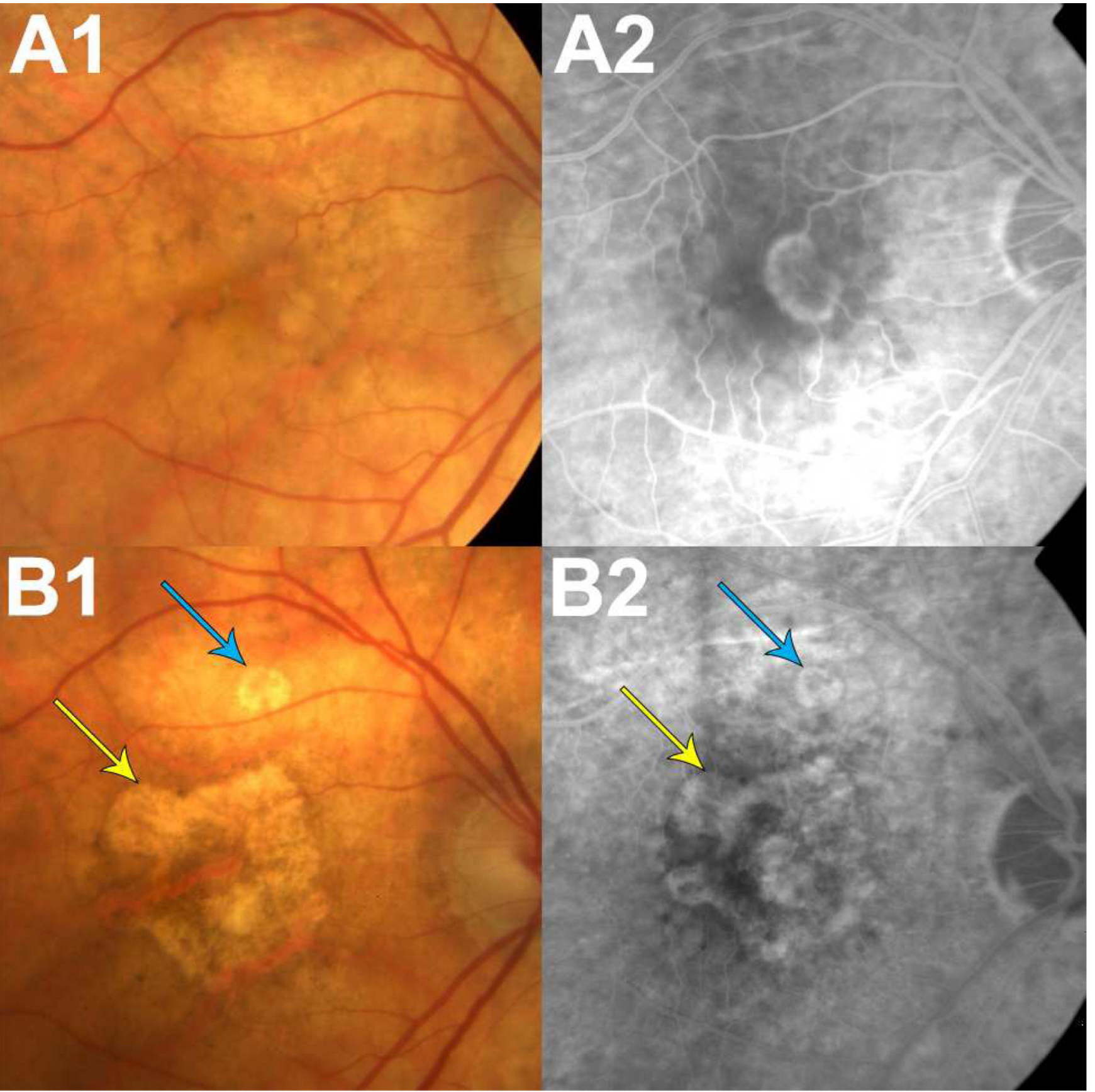

Figure 2.

Color and fluorescein angiography photographs at baseline (A1 and A2) and two years (B1 and B2). This eye with a classic neovascular choroidal neovascularization (CNV) at baseline shows at two years GA lesions associated with the total CNV lesion (B1, and B2, yellow arrows) and also outside of the area of total CNV lesion (B1 and B2, blue arrows). 
를

-

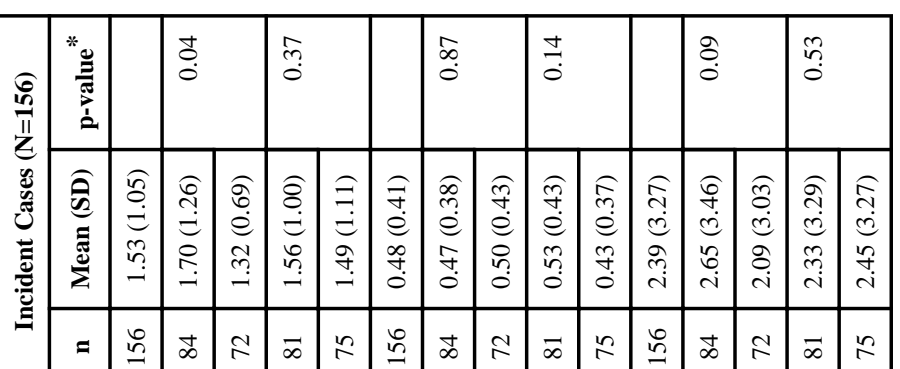

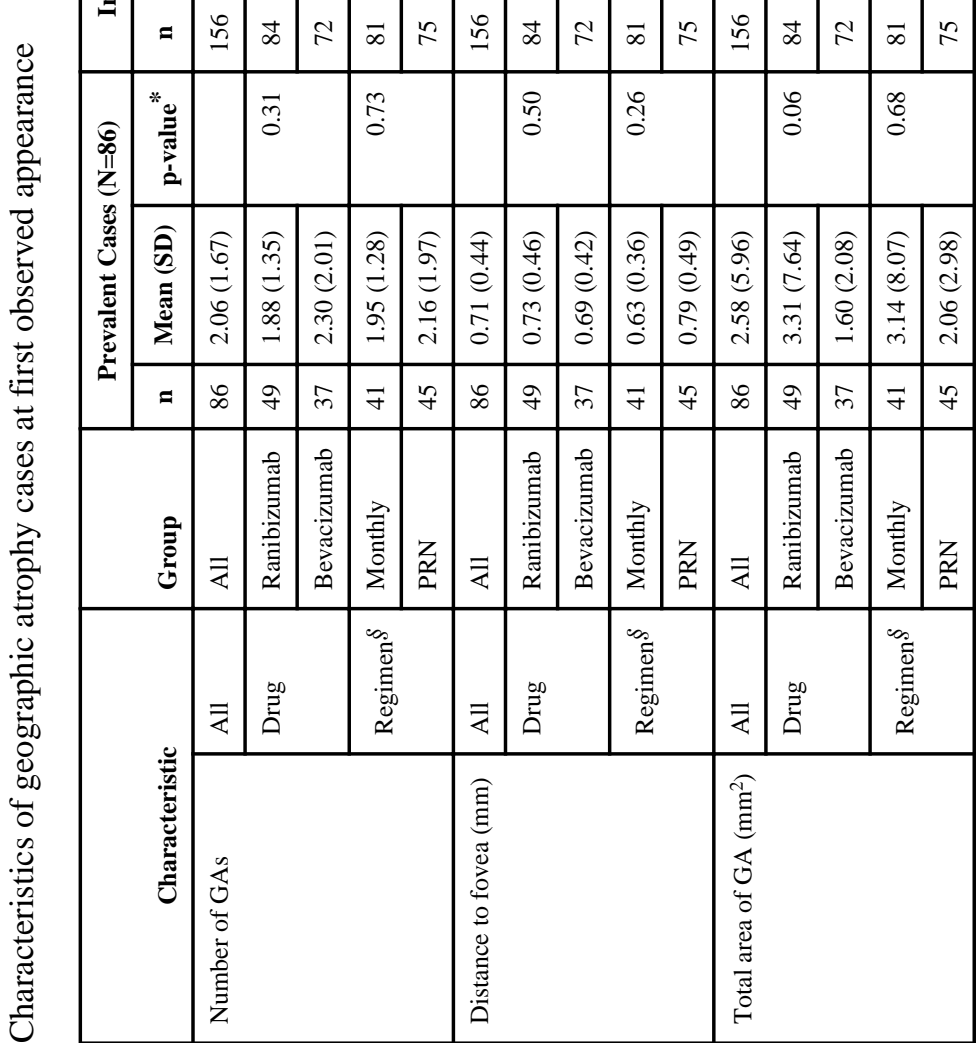


Table 2

Univariate analysis for the association between baseline factors and geographic atrophy growth rate (mm/year) within 2 years

\begin{tabular}{|c|c|c|c|c|}
\hline \multicolumn{2}{|l|}{ Baseline characteristics } & $\mathbf{n}$ & $\begin{array}{l}\text { Mean (SE) } \\
\text { mm/year }\end{array}$ & p-value \\
\hline \multicolumn{2}{|l|}{ Overall Growth Rate } & 194 & $0.43(0.03)$ & \\
\hline \multirow[t]{2}{*}{ Drug } & Ranibizumab & 106 & $0.49(0.04)$ & \multirow[t]{2}{*}{0.02} \\
\hline & Bevacizumab & 88 & $0.36(0.04)$ & \\
\hline \multirow[t]{2}{*}{ Regimen $\S$} & Monthly & 104 & $0.45(0.04)$ & \multirow[t]{2}{*}{0.68} \\
\hline & PRN & 90 & $0.43(0.04)$ & \\
\hline \multirow[t]{4}{*}{ Age (years) } & $<75$ & 32 & $0.32(0.07)$ & \multirow[t]{3}{*}{0.17} \\
\hline & $75-85$ & 123 & $0.44(0.03)$ & \\
\hline & $>85$ & 39 & $0.48(0.06)$ & \\
\hline & per 10 year increase & & $0.06(0.04)$ & 0.13 \\
\hline \multirow[t]{2}{*}{ Sex } & Female & 123 & $0.46(0.03)$ & \multirow[t]{2}{*}{0.16} \\
\hline & Male & 71 & $0.38(0.05)$ & \\
\hline \multirow[t]{2}{*}{ Cigarette smoking } & Never & 85 & $0.46(0.04)$ & \multirow[t]{2}{*}{0.39} \\
\hline & Quit/Current & 109 & $0.41(0.04)$ & \\
\hline \multirow[t]{2}{*}{ Hypertension } & No & 66 & $0.38(0.05)$ & \multirow[t]{2}{*}{0.17} \\
\hline & Yes & 128 & $0.46(0.03)$ & \\
\hline \multirow[t]{2}{*}{ Use of dietary supplements ( $\beta$-Carotene, vitamins $C, E$, and/or zinc) } & No & 65 & $0.44(0.05)$ & \multirow[t]{2}{*}{0.78} \\
\hline & Yes & 129 & $0.42(0.03)$ & \\
\hline \multirow[t]{2}{*}{ GA in fellow eye } & No & 135 & $0.38(0.03)$ & \multirow[t]{2}{*}{0.02} \\
\hline & Yes & 58 & $0.52(0.05)$ & \\
\hline \multirow[t]{2}{*}{ Prevalent/Incident GA } & Prevalent & 81 & $0.45(0.04)$ & \multirow[t]{2}{*}{0.54} \\
\hline & Incident & 113 & $0.41(0.04)$ & \\
\hline \multirow[t]{4}{*}{ Number of distinct GA lesions } & 1 & 124 & $0.39(0.04)$ & \multirow[t]{3}{*}{0.19} \\
\hline & 2 & 35 & $0.45(0.07)$ & \\
\hline & $>2$ & 35 & $0.52(0.06)$ & \\
\hline & per GA increase & & $0.03(0.02)$ & 0.18 \\
\hline \multirow[t]{5}{*}{ First Observed GA Area $\left(\mathrm{mm}^{2}\right)$} & $<1$ & 86 & $0.31(0.04)$ & \multirow[t]{4}{*}{$<0.01$} \\
\hline & $1-2$ & 47 & $0.58(0.05)$ & \\
\hline & $>2$ to 5 & 37 & $0.46(0.06)$ & \\
\hline & $>5$ & 24 & $0.47(0.08)$ & \\
\hline & per $\mathrm{mm}^{2}$ & & $0.00(0.01)$ & 0.86 \\
\hline \multirow[t]{4}{*}{ Distance to fovea $(\mathrm{mm})$} & Subfoveal & 21 & $0.32(0.09)$ & \multirow[t]{3}{*}{0.18} \\
\hline & $<0.5 \mathrm{~mm}$ & 73 & $0.39(0.05)$ & \\
\hline & $\searrow 0.5 \mathrm{~mm}$ & 100 & $0.47(0.04)$ & \\
\hline & per $\mathrm{mm}$ increase & & $0.13(0.07)$ & 0.06 \\
\hline GA completely outside the lesion & No & 167 & $0.43(0.03)$ & 0.85 \\
\hline
\end{tabular}




\begin{tabular}{|c|c|c|c|c|}
\hline \multicolumn{2}{|c|}{ Baseline characteristics } & \multirow{2}{*}{$\begin{array}{r}\mathbf{n} \\
27\end{array}$} & \multirow{2}{*}{$\begin{array}{l}\begin{array}{l}\text { Mean (SE) } \\
\text { mm/year }\end{array} \\
0.42(0.07)\end{array}$} & \multirow[t]{2}{*}{ p-value } \\
\hline & Yes & & & \\
\hline \multirow[t]{4}{*}{ Visual acuity } & $20 / 40$ or better & 56 & $0.41(0.05)$ & \multirow[t]{4}{*}{0.09} \\
\hline & $20 / 50-80$ & 79 & $0.49(0.04)$ & \\
\hline & $20 / 100-160$ & 41 & $0.31(0.06)$ & \\
\hline & $20 / 200$ or worse & 18 & $0.48(0.09)$ & \\
\hline \multirow[t]{5}{*}{ Total area of CNV lesion (disc area) } & $\Delta$ & 70 & $0.48(0.05)$ & \multirow[t]{4}{*}{0.22} \\
\hline & $>1$ to $\underline{2}$ & 36 & $0.33(0.07)$ & \\
\hline & $>2$ to $\leq 4$ & 41 & $0.46(0.06)$ & \\
\hline & $>4$ & 43 & $0.38(0.06)$ & \\
\hline & per disc area increase & 190 & $-0.00(0.01)$ & 0.77 \\
\hline \multirow[t]{2}{*}{ Location of CNV lesion } & Subfoveal & 117 & $0.37(0.04)$ & \multirow[t]{2}{*}{0.02} \\
\hline & Not Subfoveal & 77 & $0.51(0.04)$ & \\
\hline \multirow[t]{3}{*}{ CNV lesion type } & Predominantly classic & 26 & $0.68(0.07)$ & \multirow[t]{3}{*}{$<0.001$} \\
\hline & Minimally classic & 33 & $0.50(0.07)$ & \\
\hline & Occult only & 134 & $0.36(0.03)$ & \\
\hline \multirow[t]{2}{*}{ RAP lesion } & No & 158 & $0.43(0.03)$ & \multirow[t]{2}{*}{0.99} \\
\hline & Yes & 35 & $0.43(0.07)$ & \\
\hline \multirow[t]{2}{*}{ Hemorrhage (associated with lesion) } & No & 55 & $0.37(0.05)$ & \multirow[t]{2}{*}{0.21} \\
\hline & Yes & 139 & $0.45(0.03)$ & \\
\hline \multirow[t]{3}{*}{ Intraretinal fluid } & None & 19 & $0.34(0.10)$ & \multirow[t]{3}{*}{0.65} \\
\hline & Not Subfoveal & 61 & $0.44(0.05)$ & \\
\hline & Subfoveal & 110 & $0.43(0.04)$ & \\
\hline \multirow[t]{3}{*}{ Subretinal fluid } & None & 55 & $0.46(0.05)$ & \multirow[t]{3}{*}{0.59} \\
\hline & Not Subfoveal & 84 & $0.43(0.04)$ & \\
\hline & Subfoveal & 52 & $0.38(0.05)$ & \\
\hline \multirow[t]{3}{*}{ Sub-RPE fluid } & None & 80 & $0.48(0.04)$ & \multirow[t]{3}{*}{0.08} \\
\hline & Not Subfoveal & 42 & $0.43(0.06)$ & \\
\hline & Subfoveal & 57 & $0.33(0.05)$ & \\
\hline \multirow[t]{2}{*}{ Subretinal hyper-reflective material } & No & 42 & $0.38(0.06)$ & \multirow[t]{2}{*}{0.39} \\
\hline & Yes & 149 & $0.44(0.03)$ & \\
\hline \multirow[t]{2}{*}{ Epiretinal membrane } & No & 155 & $0.40(0.03)$ & \multirow[t]{2}{*}{0.04} \\
\hline & Yes & 34 & $0.55(0.07)$ & \\
\hline
\end{tabular}

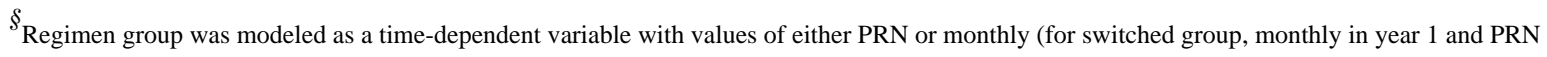
in year 2) 
Table 3

The univariate analysis for the association between genotype with geographic atrophy growth rate within 2 years

\begin{tabular}{|c|c|c|c|}
\hline SNP & Genotype & $\mathbf{n}$ & $\begin{array}{c}\text { Mean (SE) } \\
\text { mm/year }\end{array}$ \\
\hline \multirow{4}{*}{ CFH rs 1061170} & $\mathrm{CC}$ & 44 & $0.38(0.06)$ \\
\hline & $\mathrm{TC}$ & 70 & $0.43(0.05)$ \\
\hline & TT & 37 & $0.49(0.06)$ \\
\hline & Linear trend p-value & & 0.22 \\
\hline \multirow[t]{4}{*}{ ARMS2 rs10490924 } & TT & 38 & $0.47(0.06)$ \\
\hline & GT & 66 & $0.45(0.05)$ \\
\hline & GG & 47 & $0.37(0.06)$ \\
\hline & Linear trend p-value & & 0.21 \\
\hline \multirow[t]{4}{*}{ HTRA1 rs11200638 } & $\overline{\mathrm{AA}}$ & 37 & $0.48(0.06)$ \\
\hline & $\mathrm{AG}$ & 66 & $0.42(0.05)$ \\
\hline & GG & 48 & $0.40(0.06)$ \\
\hline & Linear trend $\mathrm{p}$-value & & 0.39 \\
\hline \multirow[t]{4}{*}{ C3 rs2230199 } & $\overline{\mathrm{GG}}$ & 11 & $0.61(0.11)$ \\
\hline & $\mathrm{CG}$ & 64 & $0.37(0.05)$ \\
\hline & $\overline{\mathrm{CC}}$ & 76 & $0.45(0.04)$ \\
\hline & Linear trend $\mathrm{p}$-value & & 0.94 \\
\hline \multirow[t]{4}{*}{ TLR3 rs3775291 } & $\mathrm{CC}$ & 87 & $0.42(0.04)$ \\
\hline & $\mathrm{CT}$ & 54 & $0.42(0.05)$ \\
\hline & TT & 10 & $0.53(0.13)$ \\
\hline & Linear trend p-value & & 0.64 \\
\hline
\end{tabular}

ARMS2 = age-related maculopathy susceptibility $2 ; \mathrm{C} 3=$ complement $3 ; \mathrm{SE}=$ standard error; $\mathrm{CFH}=$ complement factor $\mathrm{H} ; \mathrm{HTRA} 1=\mathrm{HtrA}$ serine peptidase $1 ;$ TLR3 = toll-like receptor 3 gene.

* The AMD risk alleles are C for CFH, T for ARMS2, A for HTRA1, G for C3, and C for TLR3 
I

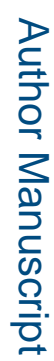

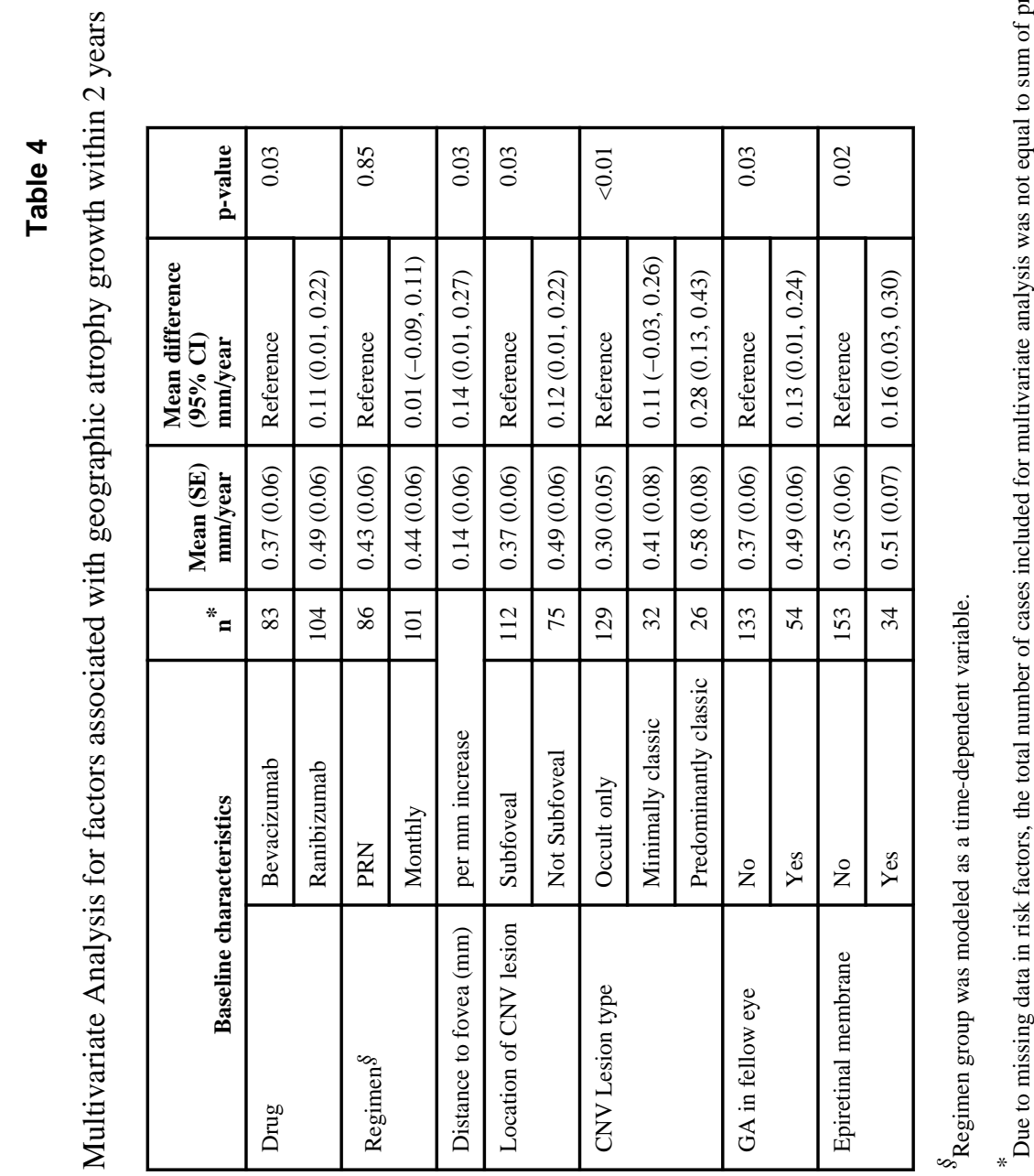

Ophthalmology. Author manuscript; available in PMC 2016 April 01. 